\title{
Når politik bliver underholdning
}

\section{AF LAURITS HARMER LASSEN OG SøREN KJELLBERG ISHøY}

Artiklen kortlægger dækningen af det amerikanske præsidentvalg 2004 i de to største amerikanske og danske aviser: USA Today, New York Times, Jyllands-Posten og Politiken. Gennem to uger er alle historier om valget i de fire aviser blevet analyseret, og det viser sig, at mellem 60 og 70 procent af alle artiklerne i de fire aviser vinklede på de politiske processer frem for den politiske substans. Samtidig viser analysen, at de danske og amerikanske avisers dækning i grove træk minder om hinanden. Artiklen foretager en demokratiteoretisk kritik af mediernes dækning og kommer desuden med mulige forklaringer på, hvorfor der bliver fokuseret mere på det politiske spil end den politiske substans.

Da USA's præsident George W. Bush og udfordreren John Kerry debatterede i tre nationale tv-debatter op til præsidentvalget $\mathrm{i}$ 2004, blev der talt politik og holdninger live for amerikanerne og resten af verden. Alligevel var det ikke de to herrers politik, der trak overskrifter. Tv, radio og aviser - både i USA og i resten af verden - bragte efterfølgende nyheden om, at 'Kerry vandt knebent' eller at 'Bush slog igen'.

Overalt havde mediernes dækning et fællestræk: Det var ikke den konkrete politik og de politiske budskaber, der var interessante - det var snarere de to kombattanters optræden. Den amerikanske valgkamp eksemplificerer en udvikling, der gælder for den politiske journalistik i USA, i Danmark og i det meste af den vestlige verden. Hvad enten det er tv-dueller, meningsmålinger, partipolitisk ævl og kævl, så er det den politiske proces og det 
politiske spil, journalisterne fokuserer på frem for den konkrete politik og de politiske visioner - det flere medieforskere betegner som procesjournalistik og en forfladigelse af den politiske journalistik.

Som specialestuderende har vi haft lejlighed til at undersøge, hvordan de to største aviser i USA og Danmark - New York Times, USA Today, Jyllands-Posten og Politiken - dækkede præsidentvalget i 2004. Vi har blandt andet set på artiklernes emner, kilder, genrer og forholdet mellem artikler, der vinkler på processerne og den politiske substans.

En komparativ undersøgelse af de respektive landes dækning af præsidentvalget er interessant i den forstand, at valget ikke bare delte den amerikanske befolkning i to næsten lige store blokke, men også viste et skel over Atlanten. Mens amerikanerne genvalgte Bush, var Kerry europæernes og danskernes mand. En meningsmåling i Jyllands-Posten 4. oktober 2004 viste, at blot 12 procent af danskerne ville stemme på George W. Bush, mens hele 58 procent af danskerne ville sætte deres kryds ved John Kerry, hvis de havde mulighed for at stemme til valget.

Danskernes og amerikanernes syn på amerikansk politik er med andre ord fundamentalt forskelligt, og spørgsmålet er, om den politiske kløft over Atlanten også kommer til udtryk i den konkrete politiske journalistik. Forskelle i den amerikanske politiske kultur og den danske ditto kunne umiddelbart - som det spejl medierne er af det omgivende samfund - tale for, at der er en divergens i den journalistiske tilgang til valgkampen i de to lande. Omvendt er det en kendt sag, at danske udlandsjournalister ofte er direkte inspirerede af deres amerikanske kolleger i dækningen af USA, og det er velkendt, at amerikansk presse siden 1920'erne har været et forbillede for den danske. Et naturligt spørgsmål i forlængelse heraf er derfor, om danske medier i det store og hele læner sig op ad de amerikanske i dækningen af præsidentvalget.

Vores analyse viser, at de største danske og amerikanske aviser i store træk dækkede præsidentvalget ens. Men dog med udsving, som denne artikel vil gøre rede for.

Samtidig viser analysen, at procesjournalistikken dominerer dækningen, og vi vil i denne artikel diskutere de demokratiske 
konsekvenser af mediernes fokus på strategi og spil. Endelig vil vi komme med bud på, hvorfor procesjournalistikken fylder så meget og på, hvorfor de danske avisers dækning i det store og hele ligner de amerikanske.

\section{Resultater}

I alt har vi analyseret 463 artikler i de fire aviser ${ }^{1}$. Tallet dækker over samtlige artikler om præsidentvalget $i$ to uger op til valget fra mandag den 18. oktober til søndag den 31. oktober 2004. Analysen kortlagde blandt andet:

- Forholdet mellem artikler, der vinkler på konkret politik (politisk indhold) og artikler, der vinkler på processen og de politiske strategier (ikke-politisk indhold).

- De emner, aviserne behandler, for eksempel 'krigen i Irak' eller 'sundhedspolitik'.

- De kilder, aviserne benytter, for eksempel 'republikanere', 'demokrater', 'eksperter' og 'almindelige mennesker'.

- De journalistiske genrer, journalisterne benytter i deres formidling. For eksempel 'nyhedsartikler' 'reportager' og 'baggrundsartikler'.

\section{Politisk indhold}

For helt overordnet at kunne identificere avisernes dækning af valgkampen, har vi som sagt opdelt alle artikler i to overordnede fortællerrammer: Politisk indhold og ikke-politisk indhold.

Med politisk indhold menes artikler, hvor politik formidles med fokus på konsekvenser, forklaringer og løsninger af et bestemt politisk emne eller problem. Der er altså tale om politiske argumenter og en forklaring af kandidaternes politik. Artikler uden politiske indhold vinkler derimod på det, man kan kalde 'spillet', dvs. på det politiske styrkeforhold, politiske strategier og kandidaterne som personer. Altså alt det, der ikke har specifikt politisk indhold.

Sondringen mellem politisk indhold og ikke-politisk indhold er ikke ny og har med forskellige benævnelser været brugt i mange analyser af amerikanske valgkampe og af mange medieforskere. Det gælder blandt andet Stanley og Niemi (1990), Ja- 
mieson (1992), Graber (1993), Rhee (1997), Capella og Jamieson (1997) og Ørsten (2004). Medieforskeren Kathleen Jamieson (1992) konstaterede allerede i 1992, at strategy coverage dominerer amerikanske valgkampe til skade for den politiske debat og modtagernes politiske engagement. Samme konklusion drager Thomas E. Patterson, der derudover har dokumenteret, at vinkling på horse race og strategi er blevet stadig mere udbredt i den amerikanske valgkampsdækning i perioden fra 1960 til 1992 (Patterson, 1993).

Vores undersøgelse viser følgende fordeling mellem artikler, der vinkler på politisk indhold og artikler, der vinkler på ikke-politisk indhold:

\section{Tabel $1^{2}$}

Artikler om præsidentvalgkampen 2004 fordelt på politisk indhold og ikke-politisk indhold. New York Times, USA Today, Jyllands-Posten og Politiken. Procent
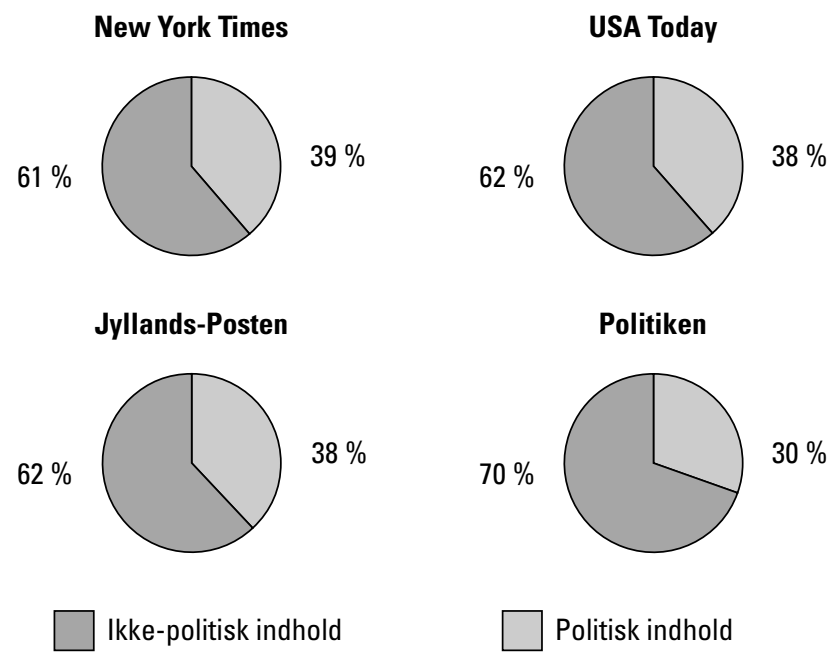

I denne kategori er tre af aviserne stort set identiske. USA Today, New York Times og Jyllands-Posten har hovedvægten på politisk indhold i lige under 40 procent af artiklerne. Politiken har med omkring 30 procent en smule færre artikler med politisk indhold end de øvrige aviser. Overordnet springer det dog i øjnene, at aviserne ligger på nogenlunde samme niveau. Det viser, at aviserne - trods vidt forskellige udgangspunkter for deres dækning - har 
samme opfattelse af, hvad der er en god historie, og at de prioriterer den samme type politiske journalistik.

En anden vigtig pointe er, at der i både de danske og de amerikanske aviser er væsentligt flere artikler uden politisk indhold end artikler med politisk indhold.

\section{Ingen altdominerende emner}

Valgkampsdækningen var præget af et meget stort antal forskellige emner, og vi har derfor ikke systematisk analyseret hvert enkelt emne. Det ville ganske enkelt være uoverskueligt. I stedet har vi set på både de emner, som aviserne fokuserer meget på, og de emner, som så at sige glimrer ved deres fravær. Det skal understreges, at vi kun har afkrydset ét emne for hver artikel, hvorfor der er tale om artiklens hovedemne.

For overskuelighedens skyld har vi i tabel 2 slået et stort antal mindre hyppige emner sammen under kategorien 'andet'.

Som det fremgår af tabel 2 har ingen af aviserne noget altdominerende emne i den undersøgte periode. Blandt de kvantitativt vigtigste emner er 'Irak' og 'krigen mod terror'. I New York Times

\section{Tabel 2.}

Artikler om præsidentvalgkampen 2004 fordelt på emner. New York Times, USA Today, Jyllands-Posten og Politiken. Procent

\begin{tabular}{lcc|cc}
\hline & $\begin{array}{c}\text { New } \\
\text { York } \\
\text { Times }\end{array}$ & $\begin{array}{c}\text { USA } \\
\text { Today }\end{array}$ & $\begin{array}{c}\text { Jyllands- } \\
\text { Posten }\end{array}$ & Politiken \\
\hline Irak & 9 & 5 & 6 & 5 \\
Sundhedspolitik & 4 & 14 & 3 & 3 \\
Valgsystem/valgkaos & 7 & 8 & 7 & 11 \\
Mediedækning/reklamer & 6 & 10 & 4 & 11 \\
Krigen mod terror & 8 & 8 & 7 & 5 \\
Meningsmålinger & 5 & 8 & 9 & 5 \\
Svingstater & 11 & 1 & 1 & 5 \\
Andet & 50 & 46 & 63 & 55 \\
\hline I alt & 100 & 100 & 100 & 100 \\
\hline
\end{tabular}


er det tilsammen de primære emner i knap 20 procent af artiklerne, i USA Today i omtrent 15 procent, mens det i Politiken og Jyllands-Posten var hovedemner i knap 10 og 12 procent af artiklerne. Gennemgående temaer i artiklerne er kandidaternes forsikringer om, at de vil slå hårdt ned på terror og gøre USA til et sikkert land at leve $i$.

Blandt de mest udbredte emner i alle aviserne er desuden 'mediedækning/reklamer', 'meningsmålinger' og et emne, vi har valgt at kalde 'valgsystem/valgkaos'. Der tegner sig et billede af, at de danske og amerikanske aviser i det store og hele skriver om de samme emner. Derudover er der enkelte emner, som er meget udbredte i en enkelt avis, men ikke fylder særligt meget i de andre. Det gælder blandt andet emnet 'svingstater', der handler om stater, som begge kandidater havde mulighed for at vinde. Det er det primære emne i over 10 procent af artiklerne i New York Times. Politiken har til sammenligning knap 5 procent artikler om det emne, mens det i USA Today og Jyllands-Posten kun er hovedemnet i omkring 1 procent af artiklerne.

Et andet emne, som aviserne dækker forskelligt er 'sundhedspolitik'. I USA Today er det hovedemnet i cirka hver syvende artikel, mens det i de andre aviser udgør mindre end hver 20. artikel. Det er specielt debatten om influenzavaccine til ældre amerikanere, der præger USA Todays dækning. Under valgkampen kom det frem, at der ikke var vacciner nok til alle, der ønskede det. Det fik begge præsidentkandidater til at kræve vaccine til samtlige ældre. En anden sundhedspolitisk debat under valgkampen var spørgsmålet om health insurance, altså i hvor stort omfang det offentlige og de private arbejdsgivere skal dække læge- og sygehusudgifter.

\section{Vigtige emner overses}

I både danske og amerikanske aviser er det bemærkelsesværdigt, at mange „tunge“ og samfundsmæssige vigtige emner kun opnåede meget begrænset eller slet ingen dækning i alle aviserne. Det gælder blandt andet arbejdsløshed, uddannelsespolitik, socialpolitik, finanspolitik og økonomisk politik, som kun får meget begrænset omtale i alle aviserne. I tabel 2 er de placeret under kategorien 'andet'. 
Et af de fraværende emner er altså det, vi har valgt at kalde 'økonomisk politik'. Det er artikler, der handler om udfordringerne forbundet med USA's store budgetunderskud, skattepolitik samt væksten i amerikansk økonomi. Disse spørgsmål var kun det primære emne i fire artikler, hvilket er bemærkelsesværdigt set i lyset af, at det galopperende offentlige budgetunderskud i 2004 udgjorde 412 milliarder dollar (Congressional Budget Office, 2005: www.cbo.gov).

Et andet bemærkelsesværdigt resultat er, at 'arbejdsløshed' stort set ikke optræder som hovedemne i dækningen i vores undersøgelsesperiode. New York Times havde en enkelt valg-artikel med arbejdsløshed som hovedemne, USA Today havde ligeledes én artikel, mens ingen af de danske aviser har dette som hovedemne i en eneste artikel. Fraværet af emnet 'arbejdsløshed' er især iøjnefaldende, fordi arbejdsløsheden steg både i absolutte tal og i procent i Bush' første embedsperiode. I november 2004 udgjorde ledigheden således 5,4 procent mod 3,9 procent, da Bush overtog præsidentposten i januar 2001 (U.S. Department of Labor, 2004: www.dol.gov).

Heller ikke emnet 'uddannelse' blev der skrevet nævneværdigt om i nogle af aviserne. Kun to artikler-én i Jyllands-Posten og én i New York Times - har uddannelse som hovedemne. Et emne som ‘socialpolitik' får ligeledes kun begrænset dækning og er blot det dominerende emne i sammenlagt syv artikler, hvoraf de fem er i New York Times.

At de tunge politiske emner ikke dækkes nær så meget som 'Irak' og 'terror' er måske ikke overraskende med tanke på USA's krig mod terror og oprørere i Irak. Men at de politiske kerneemner næsten udelades i dækningen i både de amerikanske og danske aviser springer alligevel i øjnene set med demokratiteoretiske briller.

\section{Antallet af kilder}

Mens de danske og amerikanske aviser i store træk kredser om de samme emner og vinkler historierne ens, så forholder det sig anderledes i deres brug af kilder. Her er der væsentlige forskelle.

Vores optælling viser, at New York Times er den avis, der benytter flest kilder. Avisens artikler indeholdt i gennemsnit 3,4 kilder 
per historie, mens USA Today bruger næstflest med 2,8 kilder per historie. Politiken har 2,1 kilde per artikel, mens Jyllands-Posten blot bruger 1,6 kilder per artikel.

Den store forskel i antallet af kilder mellem de danske og amerikanske aviser dækker over et meget differentieret billede. Der er eksempelvis meget stor forskel på avisernes brug af ekspertkilder. USA Today og New York Times bruger således begge o,7 ekspertkilde per historie, hvilket er dobbelt så mange som Jyllands-Posten og over tre gange så mange som Politiken.

Der tegner sig ligeledes meget store forskelle på avisernes brug af organisationskilder. Først og fremmest bruger Jyllands-Posten næsten ikke repræsentanter fra organisationer eller virksomheder som kilder i vores analyseperiode. Avisen har kun 0,1 organisationskilde per artikel, mens New York Times for eksempel benytter 0,6 organisationskilde per artikel.

De amerikanske aviser bruger også langt flere politiker-kilder end de danske aviser, mens billedet ser mere ensartet ud, når det gælder 'almindelige mennesker'. I alle fire aviser optræder der således i gennemsnit omkring 0,5 'almindelige mennesker' per artikel. Da de amerikanske aviser har markant flere kilder per artikel, står 'almindelige mennesker' med andre ord for en større andel af de danske avisers kilder. Prioriteringen af 'almindelige mennesker' som kilder i de danske medier kan ses som et forsøg på at konkretisere politikken og dermed bidrage til en større forståelse af det liv, den menige amerikaner lever.

Overordnet indikerer den meget store forskel $i$ antallet af kilder per historie en mere grundig gennemgang i de amerikanske aviser. Det er især iøjnefaldende, at Jyllands-Posten gennemsnitligt blot har 1,6 kilder per historie - mindre end halvdelen af New York Times.

Man kan indvende, at de amerikanske aviser har lettere adgang til kilderne end de danske, men det kan samtidig konstateres, at danske aviser ikke har forsøgt at kompensere for den formodede begrænsede adgang til amerikanske kilder ved for eksempel at få danske ekspertkilder til at kommentere valget.

En anden iøjnefaldende pointe i forhold til avisernes brug af kilder er fordelingen af republikanske og demokratiske kilder. Vores optælling viser, at Politiken, Jyllands-Posten og New York 
Times har flere demokratiske kilder end republikanske. USA Today har derimod præcis lige mange kilder fra begge partier. Overordnet er det altså oppositionskandidaten og hans partifæller, der får mest taletid, og ikke præsidenten og hans embedsapparat.

I de danske aviser er forskellen mere markant end i de amerikanske. I Jyllands-Posten er der cirka en tredjedel flere demokratiske kilder end republikanere, mens der i Politiken er knap 20 procent flere demokrater. I New York Times er der 8 procent flere demokrater, hvilket statistisk set er så lille et udsving, at det ikke giver anledning til håndfaste konklusioner. Det kan dog konstateres, at John Kerry og demokraternes synspunkter under alle omstændigheder er kommet på den politiske dagsorden og med tanke på, at Bush som siddende præsident er det kendte ansigt og havde hele regeringsapparatet i ryggen, kan det virke overraskende, at republikanerne kommer mindre til orde end demokraterne.

\section{Genrer}

De fire avisers artikler fordeler sig på følgende genrer:

\section{Tabel 3.}

Artikler om præsidentvalgkampen 2004 fordelt på genrer. New York Times, USA Today, Jyllands-Posten og Politiken. Procent

\begin{tabular}{lcc|cc} 
& $\begin{array}{c}\text { New } \\
\text { York } \\
\text { Times }\end{array}$ & $\begin{array}{c}\text { USA } \\
\text { Today }\end{array}$ & $\begin{array}{c}\text { Jyllands- } \\
\text { Posten }\end{array}$ & Politiken \\
\hline Nyheder/noter & 33 & 39 & 51 & 54 \\
Baggrund/analyse & 39 & 35 & 21 & 18 \\
Interview/portrætter & 2 & 6 & 6 & 8 \\
Reportager & 9 & 5 & 13 & 17 \\
Kommentarer & 17 & 15 & 9 & 3 \\
\hline I alt & 100 & 100 & 100 & 100 \\
\hline
\end{tabular}

Nyhedsartiklerne er den dominerende genre om præsidentvalget i både Politiken, Jyllands-Posten og USA Today, mens baggrunds- 
artikler er den mest benyttede i New York Times. Overordnet tegner der sig et billede af, at baggrundsartikler og kommentarer bliver brugt markant mere i de amerikanske aviser end i de danske. De danske aviser har til gengæld en relativt større andel reportager og nyheder end de amerikanske, mens ingen af aviserne benytter sig af interview-genren i nævneværdig grad.

Det større antal baggrundsartikler og kommentarer i de amerikanske aviser kan umiddelbart ses som et tegn på, at journalisterne i højere grad har forsøgt at „gå bagom nyhederne“, end de danske aviser har. Et politisk valg rummer mange komplicerede spørgsmål, og for at forstå disse kan man argumentere for, at det kræver mere end blot nyheder. Kommentarerne adskiller sig fra baggrundsartikler ved at være mere subjektive, og et højt antal kommentarer i dækningen er ikke nødvendigvis udtryk for en nuanceret dækning. Omvendt kan kommentarer, der sætter fakta og argumenter i spil, medvirke til en bedre forståelse af præsidenterne som personer og deres politik. Hvorom alting er, tegner der sig et billede af, at New York Times og USA Today har valgt at prioritere den analyserende journalistik højere end de danske aviser.

Omvendt kan man lidt firkantet sige, at de danske aviser måske kompenserer for de manglende baggrundsartikler ved et større antal reportager. Reportagerne i de danske aviser er typisk artikler, der lidt populært sagt 'tager temperaturen' på det amerikanske samfund og almindelige amerikaneres hverdag. En viden som de amerikanske avislæsere til en vis grad må formodes at besidde i forvejen.

\section{Et demokratisk problem?}

Udviklingen i retning af mere procesjournalistik og horse race i valgkampsdækningen er som tidligere nævnt ikke sket fra den ene dag til den anden. Det er påvist, at især amerikanske journalister gennem de sidste 30-40 år gradvist har valgt at vinkle mere og mere på det, der foregår bag kulisserne og politikerne som personer. Men spørgsmålet er, om det overhovedet er et problem.

Det første svar er, at det naturligvis afhænger af de øjne, der ser. Samtidig er det ikke muligt at drage håndfaste konklusioner uden 
at analysere de enkelte artikler kvalitativt. Når det så er sagt, er der ingen tvivl om, at der lurer nogle overordnede 'farer' ved procesjournalistikkens dominans.

Kritikken af den omfattende brug af fortællerrammer uden politisk indhold knytter sig implicit til mediernes demokratiske funktion som bindeled mellem politikere og borgere. Hvad enten man antager et elitært syn på demokratiteori eller har en mere deltagelsesorienteret tilgang, er det mediernes opgave at formidle saglig information, der skal ruste borgerne til at tage politisk stilling. Medieforskerne June Woong Rhee (1997) og Kathleen Jamieson (1992) har påpeget, at medierne ved at fokusere på politikerne som personer frem for på det politiske indhold ofte forenkler politiske begivenheder, og at modtagerne sjældent får et overordnet billede af den politik, kandidaterne og partierne agter at føre. Med andre ord bidrager medierne ikke til ,at uddanne“ borgerne som politisk bevidste vælgere (Jamieson, 1992: 187; Rhee, 1997: 30-31).

Jamieson (1992) og Patterson (1993) argumenterer begge for, at fokus på strategi og det politiske spil simplificerer politiske problemstillinger i en grad, at det fører til politisk passivitet. Modtagerne tager ganske enkelt kun stilling til strategierne. Det får kandidaterne til at fremstå som entertainere eller skuespillere i et horse race, mens journalisterne fungerer som kritikere, der vurderer kandidaternes strategi. I dette spil er modtagerne passive tilskuere, der skal underholdes, mens politisk substans i højere grad får folk til at reagere og involvere sig. Patterson henviser blandt andet til en undersøgelse, hvor vælgerne blev spurgt, hvilke historier i medierne de kunne huske samt deres reaktion på historien. Her viste det sig, at vælgerne stort set var indifferente over for historier uden politisk indhold, mens historier med politisk indhold i over halvdelen af tilfældene var "likely to draw a reaction from voters" (Patterson, 1993: 89; Jamieson, 1992: 166, 174). Derudover påpeger Jamieson, at politikerne ikke i samme grad bliver holdt ansvarlige for problemers opståen og løsninger. Logikken er banal: Man kan kun holde politikerne ansvarlige for politiske problemer, hvis man diskuterer problemernes opståen og mulige løsninger, det vil sige det politiske indhold (Jamieson, 1992: 191). 
Det står klart for de fleste medieforskere, at kritikken af procesjournalistikken er både oplagt og velunderbygget. Alligevel vil det efter vores opfattelse være en forenkling at hævde, at artikler uden politisk indhold er entydigt negative for den offentlige debat. Artikler om politiske strategier frem for politisk indhold kan i nogle tilfælde være et supplement til at forstå og fortolke valgkampen. Det kan for eksempel være væsentligt i det omfang, at politikeres personlige egenskaber påvirker deres politik. Eller i det omfang, at kampagnestrategier determinerer den førte politik. Politik handler med andre ord også om personer og politiske strategier. Det ændrer dog ikke ved den grundlæggende kritik af mediernes voldsomme fokus på strategi og politisk spil. De politiske visioner er ud fra et demokratiteoretisk synspunkt vigtigere end politikernes kampagnestrategier. Det er med andre ord vigtigere, hvad politikerne siger, end måden de siger det på.

\section{Hvorfor er der så meget politisk spil?}

Det er oplagte spørgsmål i forlængelse af medieforskernes kritik er, hvorfor aviserne vinkler så meget på strategi og horse race?

Vi vil her fremhæve fire forklaringer, som i forskellige varianter har været diskuteret af både amerikanske og danske medieforskere $^{3}$. For det første har journalister generelt langt større viden om strategi og politisk spil end om det politiske indhold. Politiske journalister, der følger begivenhederne tæt, har ofte indgående kendskab til politikernes indbyrdes relationer, interne partiopgør osv. Derimod er det mere tidskrævende og besværligt at sætte sig ind i kandidaternes arbejdsmarkedspolitik, uddannelsespolitik osv. Journalister er med andre ord blevet eksperter på processerne, og det er ganske enkelt lettere for journalister at skrive om spillet end politikken.

For det andet kan journalisternes nyhedsorientering spille ind, idet strategi og horse race oftere end politisk indhold er bundet op på konkrete begivenheder eller handlinger. Der er simpelthen mere nyhed i en frisk meningsmåling end i et partis økonomiske politik, der ikke ændrer sig fra dag til dag. Pointen er, at kandidaterne hele tiden positionerer sig i forhold til racet, og at der hele tiden er "friske“ nyheder om, hvad kandidaten nu gør for at vinde stemmer. Politisk substans er derimod mere statisk. Første gang 
kandidaten tager stilling til en politisk dagsorden, kan det forventes, at medierne skriver om det, men "further statements on the same issue become progressively less newsworthy" (Patterson, 1993: 61).

For det tredje kan udbredelsen af strategi og horse race skyldes, at både de amerikanske og danske aviser tilstræber en kritisk position i forhold til politikerne. Hvis aviserne fokuserede mere på det politiske indhold, synes det oplagt, at journalisterne skulle gå mere ind på politikernes præmisser. Ved at skrive om spillet fremstår journalisterne derimod mere kritiske over for politikernes motiver og handlinger, og den journalistiske selvopfattelse kan hermed have væsentlig betydning.

For det fjerde kan fokus på spillet skyldes en række tendenser i det politiske system. Partierne topstyrer generelt mere end tidligere, hvilket får journalister til at lave mere personcentreret journalistik og stille skarpt på de absolutte toppolitikere. Derudover tilrettelægger politikerne kommunikationen mere og mere professionelt, hvilket får journalisterne til at beskæftige sig med politikernes strategi og kommunikation. Her spiller den journalistiske selvopfattelse igen ind, idet fokus på strategien kan ses som en måde, hvorpå journalisterne tilstræber at ,afsløre“ politikernes motiver og fortælle om det politiske spin, de er udsat for. Endelig minder partierne mere og mere om hinanden, og når de politiske forskelle udvandes, vælger journalisterne at skrive om de strategiske kampe og personopgør.

Overordnet tyder meget altså på, at der er tale om en dobbelthed, hvor årsagen til, at spillet delvist fortrænger substansen, skal findes hos både journalister og politikere.

\section{Hvorfor dækkes valget ens?}

Det er værd at notere, at aviserne i USA og Danmark i vid udstrækning anvender de samme vinkler og skriver om samme emner. En forklaring på den påfaldende ens vinkling kan være, at de danske journalister læser amerikanske aviser og lader sig påvirke direkte af de amerikanske kollegers journalistik om valget. Altså, at det er de amerikanske mediers virkelighed, man læner sig op ad i den danske dækning af valgkampen. Vores empiri viser flere eksempler på historier fra amerikanske aviser, der dagen efter el- 
ler et par dage efter optræder med mindre eller slet ingen ændringer i de danske aviser (Lassen og Ishøy, 2005: 85-87). Det er også en kendt sag, at de danske journalister benytter sig af de amerikanske aviser, når de skal danne sig et overblik over nyhedsstrømmen.

Ud over den direkte påvirkning fra amerikanske aviser kan lighederne også skyldes, at journalistikken i de to lande er påvirket af samme normer og måde at tænke journalistik på. Journalistikken er med andre ord institutionaliseret på samme måde i USA og Danmark. Det betyder, at nyheder skabes ud fra et specifikt sæt af regler, normer og rutiner, der hersker i nyhedsinstitutioner på tværs af forskellige medier og lande (Cook, 1998; Sparrow, 1999). Som inden for så meget andet har især amerikanske normer og rutiner spredt sig til Danmark og resten af verden. Det er velkendt, at danske journalisters overordnede måde at tænke journalistik på i efterkrigstiden har været kraftigt influeret af en anglo-amerikansk tilgang, og der er ingen grund til at tro andet, end at det vil fortsætte så langt øjet rækker. Af samme grund er den amerikansk inspirerede procesjournalistik efter alt at dømme kommet for at blive.

\section{N O TER}

1. For metodisk fremgangsmåde henvises til vores speciale, 'Underholdning eller indsigt?' (Lassen og Ishøy, 2005: 11-20 og 39-46).

2. Se Lassen og Ishøy, 2005, bilagsmappe: 2-31 for optegnelse over hver enkelt artikels kategorisering.

3. Vi læner os i disse forklaringer bl.a. op ad Stig Hjarvard, professor i Film- og Medievidenskab på Københavns Universitet, og Peter Bro, lektor på Syddansk Universitet, som vi interviewede i forbindelse med vores analyser. 


\section{REFEREN CER}

Capella, Joseph N. og Jamieson, Kathleen Hall (1997): “Spiral of Cynicism: The Press and the Public good", New York: Oxford University Press.

Cook, Timothy E. (1998): “Governing with the news”, Chicago: The University of Chicago Press.

Graber, Doris (1993): "Mass Media and American Politics", Washington: CQ Press.

Jamieson, Kathleen Hall (1992): "Dirty Politics - Deception, Distraction, and Democracy", New York: Oxford University Press.

Lassen, Laurits Harmer og Ishøy, Søren Kjellberg (2005): „Underholdning eller indsigt? - det amerikanske proesidentvalg som de to største danske og amerikanske dagblade ser det", Roskilde Universitets Center.

Patterson, Thomas E., (1993): “Out of Order”, New York: Vintage.

Rhee, June Woong, (1997): "Strategy and Issue Frames in Election Campaign Coverage: A Social Cognitive Account of Framing Effects”, Journal of Communication nr. 47.

Sparrow, Bartholomew H. (1999): "Unicertain Guardians - The news media as a political institution", Baltimore : The Johns Hopkins University Press.

Stanley, H. og R. Niemi, (1990): "Vital Statistics on American Politics", Washington DC: CQ Press.

Ørsten, Mark (2004): “Transnational Politisk Journalistik”, Skriftserie for Journalistik på RUC.

\section{H JEM MESIDER}

Congressional Budget Office (2005): www.cbo.gov

Project for Excellent Journalism (2005): www.journalism.org

U.S. Department of Labor (2004): www.dol.gov 